\title{
European Union Emissions Trading System with Regard to Climate Change Mitigation in Latvia
}

\author{
Ilze Pruse, University of Latvia
}

\begin{abstract}
The goal of this paper is to analyse the volumes of greenhouse gas (GHG) emissions from the European Union Emissions Trading System's (EU ETS) participants in Latvia in relation to their participation therein. After describing and discussing the EU ETS mechanism and its operation in Latvia in the period 2005-2010, the interconnectedness between the GHG emissions and the EU ETS participants' operation is analysed. The analysis concludes that, although the EU ETS has contributed towards GHG emission reduction, due to the growth of the economy, overall GHG emissions from the EU ETS participants in Latvia are increasing.
\end{abstract}

Keywords - tradeable permits system, European Union Emissions Trading System, greenhouse gas emissions

\section{INTRODUCTION}

Latvia is included in the framework of the European Union Emissions Trading System (EU ETS). The EU ETS was launched on 1 January 2005 and is a cornerstone of the European Union's policy to combat climate change. The system is the EU's key tool for the cost-effective reduction of industrial greenhouse gas (GHG) emissions.

The goal of this paper is to analyse the volumes of GHG emissions from the EU ETS participants in Latvia in relation to their participation therein. The main tasks of this paper are to identify whether the EU ETS in Latvia imposes any direct incentives for the GHG emissions' reductions and to research the interconnectedness between GHG emissions and operation of the EU ETS participants. For these purposes the author shall use methods of statistical analysis (dynamics analysis, correlation analysis, etc.), as well as the results of previously performed survey.

At the beginning of this paper the EU ETS mechanism is discussed in the context of climate change mitigation and with regard to key aspects of operating a tradeable permits system . Afterwards the operation of the EU ETS in Latvia is described with an emphasis on aspects that might contribute towards GHG emissions reduction, especially free-of-charge allocations of European Union Allowances (EUAs) versus EUAs to be surrendered as well as financing gained through trading of EUAs. Further, the interconnectedness between GHG emissions and the EU ETS participants' key financial indicators is analysed, inter alia, turnover, value of fixed assets etc. For purposes of this analysis, the author has obtained, filtered, decoded and processed data from the official data base on companies registered in Latvia (Lursoft) [11] and from Community Independent Transaction Log hosted by the European Commission [2, 3, 4], leading provider of carbon credits markets' news and research -
Thomson Reuters Point Carbon [14], as well as from annual reports of installations participating in the EU ETS as published on the web site of the Latvian Environment, Geology and Meteorology Centre [9]. Quantitative analysis is supported with results of a survey of Latvia's companies participating in the EU ETS, done by the author in 2011 (invitations for the participation in the survey were sent out to all participants of the EU ETS (in 2011 - 56 companies)) and 35 responses were received, i.e. there was a $63 \%$ response rate.

In order to ensure the best representation, unless specified otherwise, the quantitative analysis is performed with regard to each participant of the EU ETS in Latvia. The principal analysis is done for the period 2005-2010. Because data about transactions are available only for the period 2005-2007 certain assumptions are made in the analysis of transactions from the year following 2007. Changes in prices of EUA are not considered as factor influencing the reduction of GHG emissions. As financial details of transactions within the EU ETS are confidential, the author assumes that the price of EUA is equal to the average price of EUAs forward prices at the date of the respective transaction. Within this paper, the author does not consider the EU ETS impact on its indirect participants and any third parties. The efficiency of the EU ETS is also not evaluated herein. The analysis herein is performed with due regard to the fact that the European Commission filed an appeal on 30 May 2011, recognising the fact that the ruling of the Court of Justice of the European Union dated 22 March 2011 [8] has been followed and Latvia has received 14.3 million additional EUAs. Unless specified otherwise, all sums are expressed in Latvia's lats $(1 \mathrm{LVL}=$ 0,702804 EUR).

\section{EU ETS as A Climate Change Mitigation Measure}

The EU ETS is a tradeable permits system. A tradeable permits system is an economic instrument that establishes a tradeable permits market with the aim at minimal costs to achieve the rationalization of the volumes of certain assets denoted by permits. The concept of tradeable permits system first was formulated at the end of the 1960s by T. Crocker [5] and J. Dales [6], and later formalized by W. D. Montgomery [12] and T. H. Titenberg [13]. The main elements of tradeable permits systems are tradeable permits, permits registries and participants of permits markets (either direct or indirect).

Tradeable permits within the EU ETS denote volumes of GHG emissions and are called European Union Allowances (EUAs). An EUA is equal to one metric ton of $\mathrm{CO}_{2}$ equivalent $\left(\mathrm{CO}_{2} \mathrm{e}\right)$ emissions. According to the estimations of the World 
Bank, the total value of EUAs in 2010 was 119.8 billion USD and accounted for $84 \%$ of the total value of the global carbon market [8]. EUAs are kept in the national registries of allowances linked with the Community Independent Transaction Log hosted by the European Commission and International Transaction Log created under the Kyoto Protocol to the United Nations Framework Convention on Climate Change [15].

Direct participants of the EU ETS are installations from power generation, district heating and energy intensive industries, however from 2012, the EU ETS also includes GHG emissions from flights to and from European airports. The EU ETS covers over 11500 installations across 27 European Union Member States as well as Iceland, Liechtenstein and Norway. GHG emissions from these installations account for over $40 \%$ of total emissions in these countries $[5,8]$.

The EU ETS is an internationally regional "cap and trade" type tradeable permit system. Within the EU ETS, the maximum volume of GHG emissions ("cap") is determined by the European Commission in consultation with the member states of the EU ETS whereas the price of GHG emissions, i.e. the price of EUAs, is determined by the market participants . Operation of the EU ETS is structured into partly linked trading periods - the first period was from 2005 to 2007, the second - 2008 to 2012, and the third will start in 2013 and continue till 2020. Within the $1^{\text {st }}$ period the GHG emissions "cap" intended to reduce its participating countries' GHG emissions by an average of 5.2\% compared with GHG emissions volumes in 1990 . Within the $2^{\text {nd }}$ period GHG emissions on average are "capped" at $6 \%$ below 2005 levels. In $3{ }^{\text {rd }}$ period the EU ETS will ensure even further cuts in GHG emissions (by $21 \%$ below 2005 levels or more). [5, 8]

Following the determination of caps annually by the end of February, competent authorities issue free-of-charge allocated EUAs to direct participants of the EU ETS. Within the $1^{\text {st }}$ period at least $95 \%$ of EUAs and within the $2^{\text {nd }}$ period at least $90 \%$ of EUAs were allocated free-of-charge. From the start of the $3^{\text {rd }}$ period, however, more than half of EUAs are expected to be auctioned. EUAs issued for the $1^{\text {st }}$ period are not valid for use in the $2^{\text {nd }}$ period, whereas EUAs issued for the $2^{\text {nd }}$ period are valid in the $3^{\text {rd }}$ period. Thus, in theory, this could help to stabilise the EUAs price and provide a longer perspective for investments. Each participating installation has an annual obligation within four months after the end of the year to surrender EUAs equal to GHG emissions, as verified. If the installation does not fulfil this obligation, a penalty is applied for each ton of GHG emissions for which no EUA is surrendered. $[5,8]$

With regard to the abovementioned, the author acknowledges the essential significance of the EU ETS in the reduction of GHG emissions and climate change mitigation in Europe. Recognising that EU ETS implementation depends on the particular local circumstances, the author shall discuss the EU ETS implementation in Latvia in the next section of the paper in order to establish the EU ETS impact on the GHG emissions reduction in Latvia.

\section{EU ETS IMPLEMENTATION IN LATVIA}

In 1990 the total amount of GHG emissions in Latvia was $25894220 \mathrm{tCO}_{2} \mathrm{e}$. Whereas in 2004 the total amount of GHG emissions in Latvia was by almost $60 \%$ lower, i.e. in 2004 GHG emissions were only $10746000 \mathrm{tCO}_{2} \mathrm{e}$. The largest source of GHG emissions in 2004 was transport sector, but the total amount of GHG emissions from the EU ETS installations in Latvia was only $2939000 \mathrm{tCO}_{2} \mathrm{e}$ or $27 \%$ from total GHG emissions. [1]

Considering the abovementioned, the author recognizes that the proportion of the EU ETS installations' GHG emissions from the total volume of Latvia's GHG emissions is considerably smaller than on average in the EU ETS member states. The author concludes that the EU ETS has very limited possibilities to significantly influence climate change mitigation in Latvia. However since any GHG emission reductions are important, the author shall continue an analysis of the EU ETS role in climate change mitigation at the level of particular installations participating in the EU ETS.

Since 200578 companies and 1 municipal agency have participated in the EU ETS from Latvia. The largest number of participants is in the $1^{\text {st }}$ period of the EU ETS whereas afterwards it decreases from 69 participants in 2007 to 60 participants in 2009 and 57 participants in 2010. Most of the EU ETS participants in Latvia are mandatory participants, e.g. in 2010 the mandatory participants were 51 companies and there were only 4 voluntary participants and 2 companies which had both installations which were mandatory participants and installations which were voluntary participants. However it is interesting to note that, although the number of mandatory participants (installations) has increased from 68 in 2005 to 70 in 2010, the number of voluntary participants (installations) has significantly decreased, i.e. from 23 in 2005 to only 7 in 2010 (decrease by more than $30 \%$ ).

$42 \%$ or 33 companies that have ever participated in the EU ETS in Latvia are from the energy sector, including all the largest energy sector companies (Fig.1). An equal number of companies is from industry sector, including the most significant producers of cement, glass, bricks, iron and steel. 3 companies are from agriculture sector, 3 from transportstorage sector, 2 from water management sector, 2 from trade sector, 1 from construction sector and 1 from property management sector.

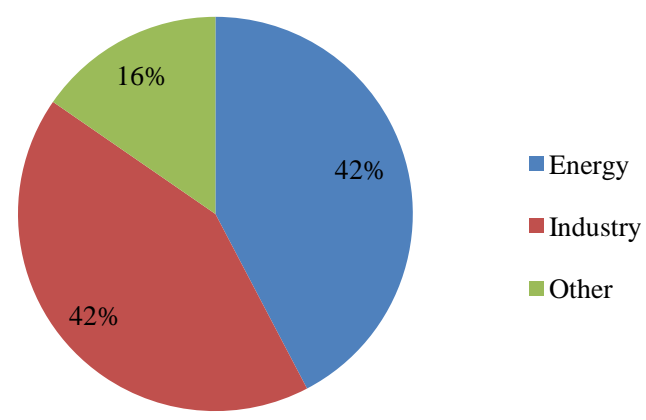

Fig. 1. Economic sectors of primary operation of Latvia's companies participating in the EU ETS (percentage of total number Latvia's companies participating in the EU ETS) $[3,11]$ 
Considering the overall classification and dynamics of the EU ETS participants in Latvia, inter alia their status of participation in the EU ETS (most are mandatory) and economic sectors of their primary operation (almost all energy sector companies are included), the author concludes that the EU ETS has a potential of influencing all principal sectors of Latvia's economy, however, due to the small number of the EU ETS participants in Latvia the impact of the EU ETS on Latvia is rather limited. An exception to this is the energy sector which is covered by the EU ETS and which impacts every person and economic entity, In addition, the author acknowledges that since the energy sector largely depends on the overall economic situation, i.e. if the economy is growing, the energy sector has to grow as well, GHG emissions from the energy sector are more difficult to control and within certain situations they might be even out of the control of energy sector companies. The author also notes, that, in general, due to international competition and customers' freedom of choice, the industry sector companies are more vulnerable with regard to the additional obligations and costs related to participation in the EU ETS. Further the author shall analyse allocations of EUAs in relation to the verified GHG emissions, i.e. amount of EUAs actually needed to ensure compliance within the EU ETS.

The author has established that the amount of total free-ofcharge allocated EUAs in Latvia in 2005-2010 in general are considerably larger than verified GHG emissions thus creating significant surpluses of EUAs (Fig.2). In the $1^{\text {st }}$ period Latvia's companies needed only around $70 \%$ of free-of-charge allocated EUAs, but in the first part of the $2^{\text {nd }}$ period - around $92 \%$ of EUAs. However, at the same time there are also some companies which free-of-charge have not received enough EUAs. By the end of the $1^{\text {st }}$ period there were no companies with deficits of the EUAs but by the end of 2010 thirteen companies had actual deficits of EUAs. The author recognizes that considering on overall large over-allocation of free-ofcharge EUAs, the EU ETS does not impose significant constraints on its participants in Latvia and mostly it is an opportunity to gain additional profits by selling surpluses of EUAs, i.e. due to sufficient free-of-charge allocations of EUAs, companies are not forced to invest in GHG emissions reductions and related technologies conversion or improvement.

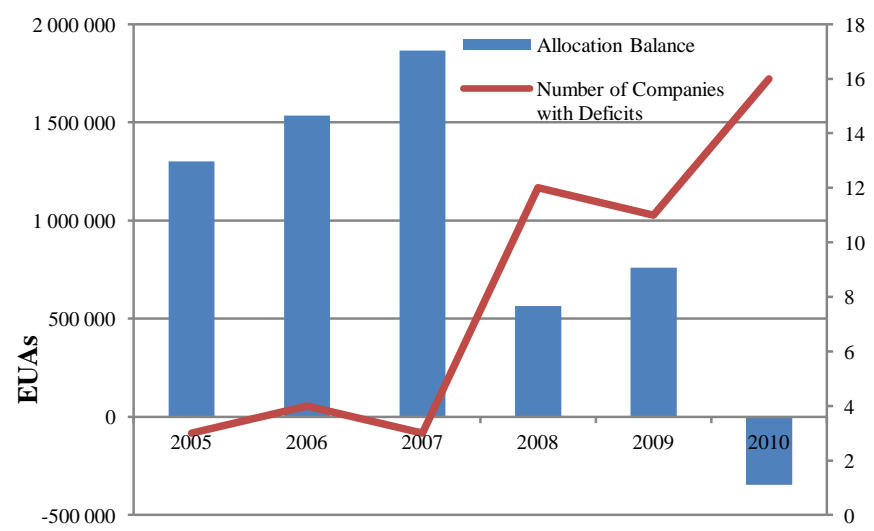

Fig. 2. Balances of free-of charge allocations of EUAs and companies with deficits of EUAs [1, 3]
Notwithstanding the aforementioned, the author would like to note that there are particular cases, especially in the $2^{\text {nd }}$ trading period, when the EU ETS might particularly have fostered some changes within companies' operation (especially in companies which experienced deficits of EUAs and companies which were using very old and inefficient technologies). In addition, the author would like to point out that although the EU ETS in Latvia generally is not imposing direct pressure towards the need for GHG emissions reductions, the fact that the EU ETS for Latvia's companies provides opportunities for gaining additional profits might indirectly contribute towards GHG emissions reductions.

The author has established that the first transaction (sale) of EUAs in Latvia (transaction from Latvia's national register of EUAs) was done on 6 December 2005, whereas since then till the end of 2007 Latvia's participants of the EU ETS have performed 236 inter-companies' transactions, including 199 sale transactions and 37 purchase transactions (Fig.3). The total volume of these transactions is 3951693 EUAs, i.e. 3313534 EUAs sold and 638150 EUAs purchased. The largest volume of transactions is in 2006 (almost $90 \%$ of transactions in $1^{\text {st }}$ period) and almost half of all transactions are performed by two companies - JSC Latvenergo (only sales transactions) and Ltd. Latgales energija (both sales and purchases transactions). Overall the sales of EUAs were performed by 43 companies, whereas purchases of EUAs were performed by 11 companies.

Assuming that the proportion of EUAs sold in 2008-2010 is similar to the proportion of EUAs sold in 2005-2007, i.e. $\sim 60 \%$ (excluding companies which have sold less EUAs than purchased), the author has estimated that the total volume of sales in 2008-2010 could be almost 1.3 million EUAs. However, at the same time it is important to note that at the end of the $1^{\text {st }}$ period (as of 31 December 2007), the trading balance of EUAs for 2 Latvia's companies was negative, i.e. they purchased more EUAs than sold (Ltd. Kalnciema kiegelis, Ltd. KP tehnologijas).

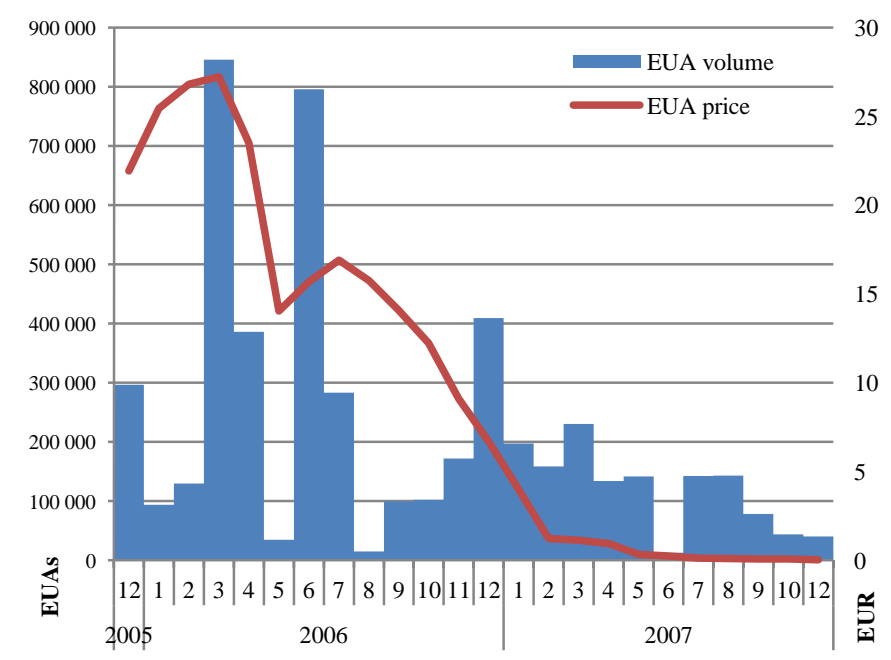

Fig. 3. Volumes of EUAs transactions of the EU ETS participants in Latvia and respective average prices of EUAs $[1,3]$ 
The total value of transactions in 2005-2007, according to author's estimations (assuming that the price of transferred EUAs is the average price of EUAs spot contracts and EUAs forward contracts with deliveries by the end of 2007, 2006 and 2005, if feasible, on the date of transaction), is 70022383 EUR (61 979981 EUR for EUAs sold and 8042402 for EUAs purchased) and total income is 53937579 EUR (Fig.4).

The largest overall value of transactions was achieved in 2006 whereas in 2007, despite the noticeable volumes of transactions due to the very low price of EUAs, the transaction value was rather low. Moreover, according to the author's estimations, 3 companies which in 2007 sold their EUAs did not even get enough income to cover the costs of transaction fee within the registry.

According to the author's estimations, the maximum value of surplus EUAs (assuming that every surplus EUA is sold only one time), however, at the respective years' maximum price (29.45 EUR in 2005, 30.31 EUR in 2006, 0.06 EUR in 2007, 31.77 EUR in 2008, 16.65 EUR in 2009 and 16.84 EUR in 2010) is more than 95 millions EUR in 2005-2007 and more than 45 millions EUR in 2008-2010. The author concludes that within the $1^{\text {st }}$ period the EU ETS participants have achieved only around $56 \%$ of income they could have achieved. Moreover, it is interesting to note that, according to the author's estimations, one company even experienced severe losses, i.e. more than 1.5 million EUR due to a very unsuccessful trading strategy.

Considering the analysis of data on transactions of the EU ETS participants in Latvia described above, the author concludes that, although the EU ETS could have provided almost at least twice as much income for its direct participants, the income it has provided is very significant and might have contributed towards the investments in technologies conversion from fossil to renewable energy resources or technologies efficiency improvement thus resulting in GHG emission reductions and climate change mitigation. Therefore in the next section of this paper the author shall analyse a possible interconnectedness between GHG emissions and companies operation thus trying to determine any evidence of purposeful reductions of GHG emissions.

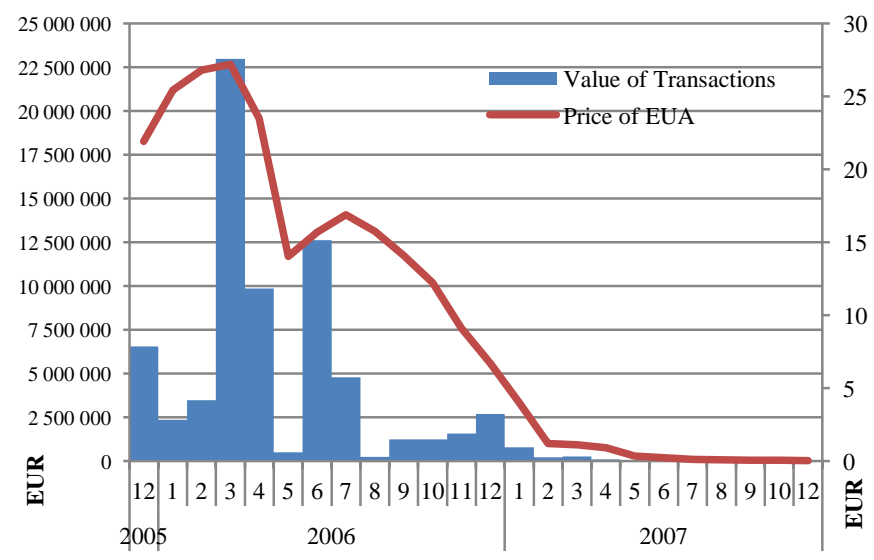

Fig. 4. Values of EUAs transactions of the EU ETS participants in Latvia and respective average prices of EUAs [2, 4, 14]

\section{EU ETS IMPACT ON ITS PARTICIPANTS' GHG EMISSIONS IN LATVIA}

The total amount of GHG emissions from the EU ETS participants in Latvia in 2006 was slightly above their total GHG emissions in 2005, however between 2006 and 2009 these figures decreased (especially significantly between 2008 and 2009 which mostly can be attributed towards the influence of the economic crisis) and sharply increased in 2010. In order to establish the reason for these changes, the author shall further analyse GHG emissions amounts interconnectedness with the number of installations, turnover, total nominal input heat power and investments in fixed assets. For the purposes of this analysis from the collected data set of 79 participants of the EU ETS in Latvia, the author shall exclude data about the municipal agency PA Malkalne (because there is no data about its commercial activities) and about those companies the installations of which entered the EU ETS with no GHG emissions (Ltd. Talsu BIO-energija and JSC Jekabpils labiba), as well as companies which participated in the EU ETS for less than 3 years (Ltd. AKD Logistik, Ltd. Aurora Baltik and Ltd. Tennere). In addition, the author excluded from an analysis 4 interrelated companies which during the analysed period several times internally changed ownership (JSC Lode, Ltd. Livanu kiegelis, Ltd. Lodes kiegelis, Ltd. Kalnciema kiegelis and Ltd. Lat Spartaks). The author summarised data about GHG emissions of installations owned by the same company .

Analysing the dynamics of the number of installations participating in the EU ETS, the author has established that within 2005-2010 there is no strong relationship between the amount of GHG emissions and the number of installations the correlation coefficient is close to zero (Fig.5.).

With regard to the abovementioned the author concludes that in 2005-2010 changes in the number of installations most likely did not significantly influence GHG emissions of the EU ETS participants in Latvia, i.e. GHG emissions decreased and increased notwithstanding the number of installations. That is especially evident in 2010 when there is a sharp increase of GHG emissions and a continuous decrease in the number of installations. The author notes that most likely during 2005-2010 there was an increase in the size of installations.

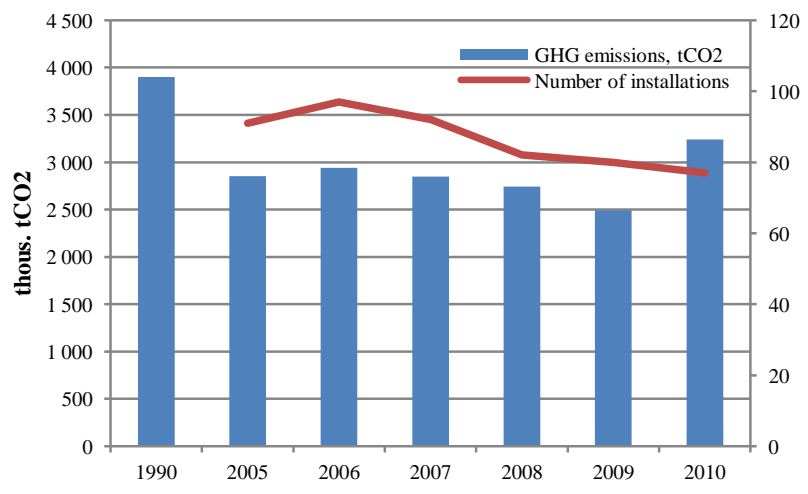

Fig. 5. Number of installations participating in the EU ETS and their GHG emissions $[1,3,9]$ 
Analysing turnover the author has established that since 2005 the turnover of companies participating in the EU ETS has gradually increased from 1000 millions EUR in 2005 to almost 2000 millions EUR in 2010 (except a since 2005 of total turnover $\mathrm{x}$ between 2008 and 2009) (Fig.6.). The correlation coefficient between the values of turnover and GHG emissions, if estimated for each year and for each company together, is 0.77 . However, if separately estimated for particular companies, the correlation coefficient for almost $33 \%$ of companies is above $|0.8|$ whereas for 11 companies or $18 \%$ of them the correlation relationship is negative, i.e. while turnover is growing GHG emissions are decreasing.

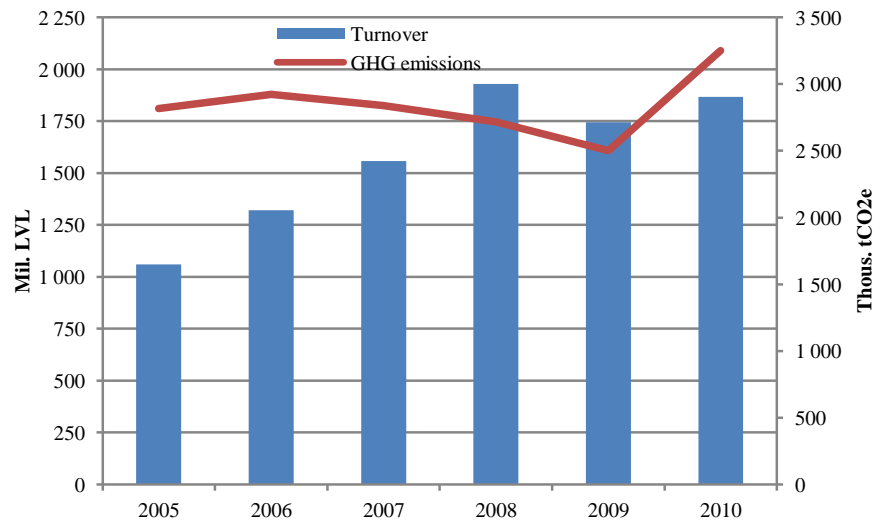

Fig. 6. Turnover of companies participating in the EU ETS in relation to their GHG emissions $[1,3,9,11]$

With regard to the above the author concludes that the turnover in 2005-2010 has a strong interrelationship with GHG emissions. Moreover, this relationship in most cases is of opposite direction (while turnover increases, GHG emissions decreases) thus indicating possible improvements in the operation efficiency of companies, e.g. conversion or improvement of technologies.

Analysing the total nominal input heat power the author has established that it has significantly fluctuated since 2005 , however after a very sharp decrease between 2005 and 2006 (decrease of $10 \%$ ) the levels of 2005 were almost regained in 2010 (Fig.7.).

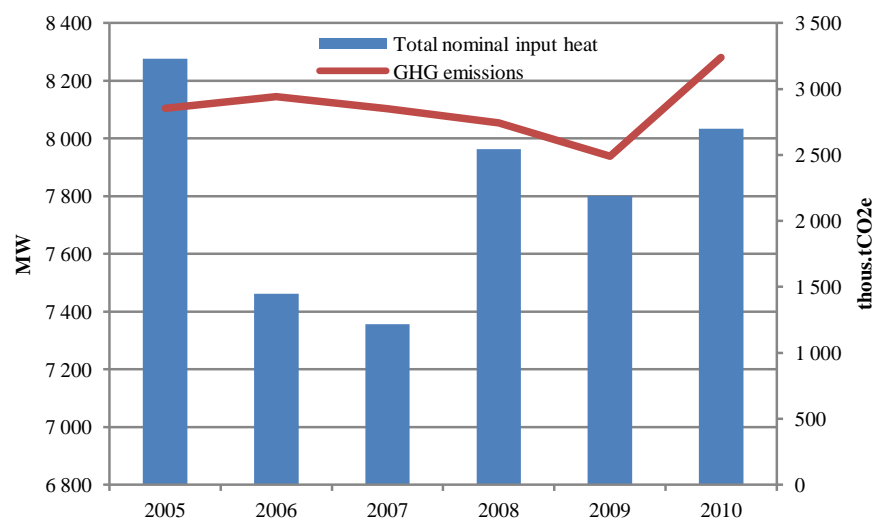

Fig. 7. Total nominal input heat power of companies' participating in the EU ETS in relation to their GHG emissions $[1,3,9]$
The correlation coefficient between the values of total nominal input heat power and GHG emissions, if estimated for each year and for each company together, is close to zero. However, the author recognizes that in order to precisely establish the relationship between the total nominal input heat power and GHG emissions, since almost half of companies participating in the EU ETS are industrial companies and in some cases they only produce electricity (not heat energy), it is necessary to more significantly narrow the analysed set of companies.

With regard to the abovementioned the author concludes that the current analysis does not provide enough evidence to properly assess the relationship between the values of total nominal input heat power and GHG emissions.

Analysing total value of fixed assets the author has established that since 2005 it has considerably increased (by almost 65\%) (Fig.8.). The correlation coefficient between the value of fixed assets and GHG emissions, if estimated for each year and for each company together, is 0.82 . However, if separately estimated for particular companies, the correlation coefficient for more than $25 \%$ of companies is above $|0.8|$ and for 12 companies it is even above $|0.9|$. It is also important to note that in case of 11 companies this correlation relationship is of opposite direction, i.e. increase of the total value of fixed assets is related to the decrease of GHG emissions.

With regard to the abovementioned the author concludes that the value of fixed assets in 2005-2010 has a strong relationship with GHG emissions. The author recognises that this strong correlation between the increase of the value of fixed assets and the decrease of the GHG emissions most likely is due to the investments in technologies improvements or conversion from energy resources with relatively high GHG emission factor to energy resources with relatively low or "zero" GHG emission factor.

However, the author acknowledges that because of shortness of data row as well as the analysed period's concurrence with several economically essential events, such as accession to the European Union (in 2004) and economic crisis (in 2008-2009), the application of statistical analysis herein is very limited. Therefore, the results of the above analysis, will be supported with results of a survey of EU ETS participants conducted by the author in 2011 .

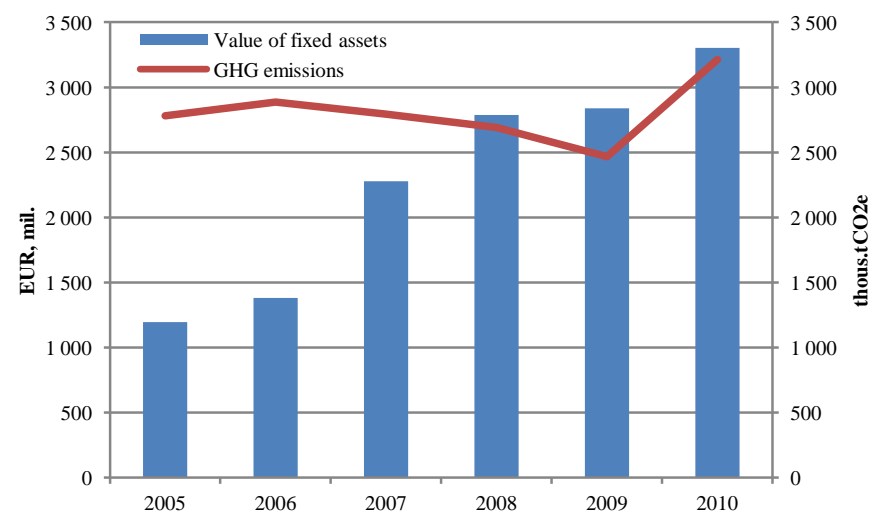

Fig. 8. Value of fixed assets of companies' participating in the EU ETS in relation to their GHG emissions $[1,3,9,11]$ 
The survey demonstrates that $43 \%$ of respondents consider that the $1^{\text {st }}$ period of the EU ETS generally was 'almost efficient' or 'efficient' in achieving its goal -GHG emission reduction at the lowest cost possible. Whereas with respect to the $2^{\text {nd }}$ period, the proportion of such like-minded respondents increased considerably, i.e. $49 \%$ considers the implementation of the EU ETS as 'almost efficient', 20\% - 'efficient' and 1 respondent stated that the EU ETS is 'very efficient'. The proportion of respondents who consider the implementation of the EU ETS as very inefficient or inefficient decreases from $54 \%$ regarding the $1^{\text {st }}$ period to $25 \%$ regarding the $2^{\text {nd }}$ period. (Fig.9.)

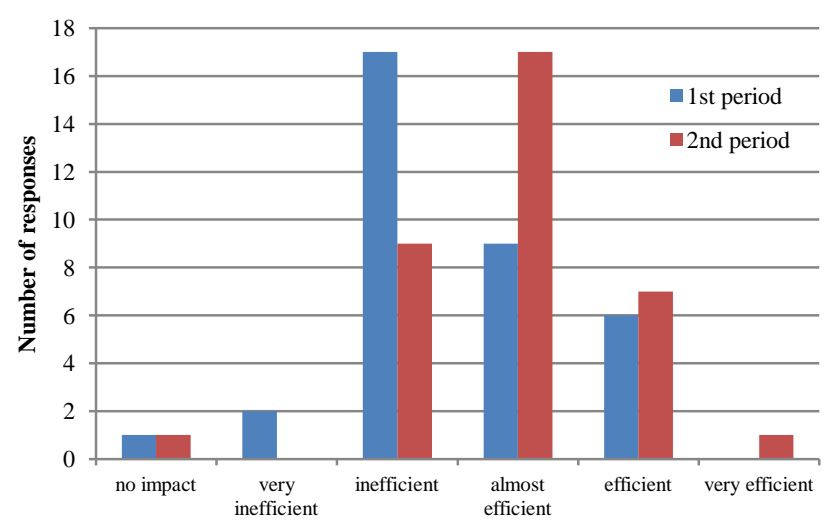

Fig. 9. Summary of responses to the question „Whether, to your opinion, the EU ETS is efficient in achieving its goal - the GHG emission reduction at least possible costs?"

With regard to the abovementioned the author concludes that the majority of EU ETS participants in Latvia hold a view that the EU ETS in general promotes GHG emissions reduction at least possible costs and thus contributes towards the climate change mitigation.

$79 \%$ of respondents in the survey answered that the EU ETS has either slightly or significantly promoted GHG emissions reduction in their company particularly (Fig.10.).

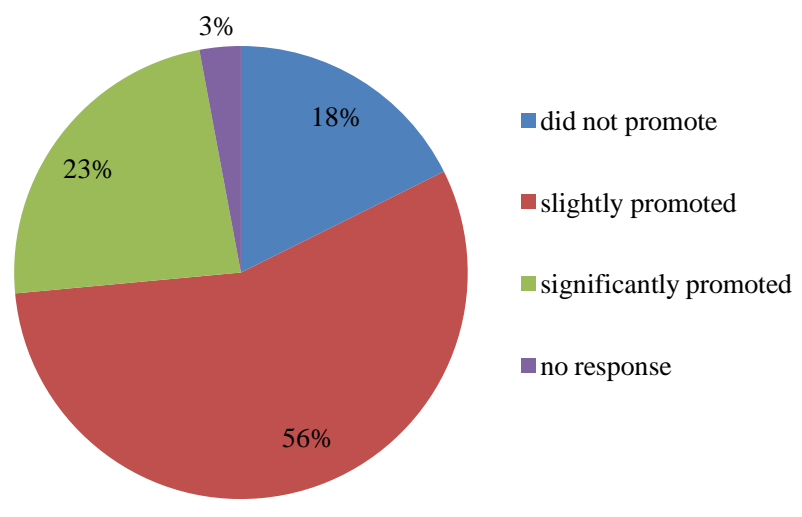

Fig. 10. Summary of responses to the question "How much did the participation in the EU ETS promote the GHG emissions reduction in your company?" (percentage of total number of respondents).

The above leads the author to conclude that a generally positive judgement about the efficiency of the EU ETS is based on respondents' personal experience and the fact that the EU ETS to a certain extent has promoted GHG emissions reductions in their companies. In other words, there is a high degree of certainty that the EU ETS indeed has promoted reductions of GHG emissions.

However, not to exaggerate the role of the EU ETS in the GHG emissions reductions, it is important to note that most of the respondents $(77 \%)$ also indicate that GHG emissions reduction is not their sole goal, i.e. mostly it is a side effect of the achievement of other goals.

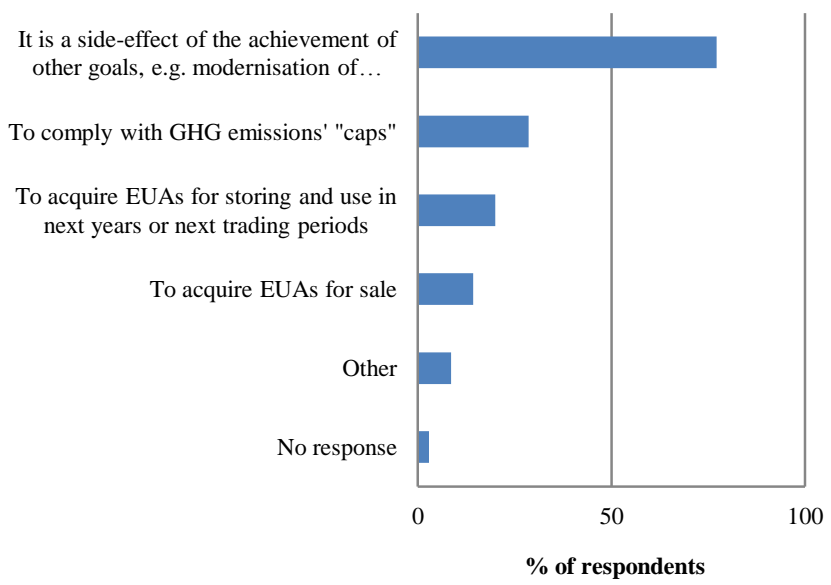

Fig. 11. Summary of responses to the question ,Why did your company plan or plans to implement activities for GHG emission reduction?"

Thus the author concludes that it is appropriate to say that in Latvia the EU ETS in 2005-2010 was not a strong incentive for GHG emissions reductions. At the same time, however, the EU ETS has been one of the arguments in favour of the reduction of GHG emissions.

In order to complete the analysis of the EU ETS impact on climate change mitigation in Latvia in 2005-2010, it is necessary to collect and analyse data about transactions within the EU ETS in 2008 - 2010 (such data shall be publicly available in 2015). Moreover, it is necessary to collect and analyse data about particular uses of proceeds from trading within the framework of the EU ETS. However, notwithstanding the lack of data, it is already possible to conclude that, although the EU ETS definitely is one of the measures for promotion of GHG emissions reduction and climate change mitigation in 2005-2010 in Latvia, the role of the EU ETS was rather small and indirect. Analysing the financial data of the EU ETS participants it becomes very clear that, although in 2005-2010 there is much evidence of qualitative improvements of the operation of companies (most likely - technology conversion or improvement), the dynamics of the GHG emission amounts are very strongly influenced by the company's scale of operation (turnover).

\section{CONCLUSIONS}

1. The EU ETS is one of the measures for climate change mitigation in Latvia, however, the proportion of the EU ETS installations' GHG emissions in the total volume of Latvia's GHG emissions is very small and 
considerably smaller than on average in the EU ETS member states.

2. The EU ETS in 2005-2010 in Latvia provided incentives for GHG emission reduction only in a few cases, however, in the future, due to the changes in the mechanism of initial allocation of EUAs, the role of the EU ETS might increase.

3. Most of the EU ETS participants in Latvia have participated in the trading of EUAs and although they have earned only a little bit more than half of what they could have earned, the EU ETS to them has provided a significant amount of additional financing and might have contributed towards investments in technologies thus resulting in GHG emission reductions and climate change mitigation.

4. The EU ETS participants in Latvia recognise the importance of the EU ETS with regard to GHG emissions reductions, however, at the same time, they note that the GHG emissions reduction generally is a side effect of the achievement of other goals.

5. There is a strong relationship between the increase of the value of fixed assets and the decrease of GHG emissions in Latvia and with regard to the constant or decreasing number of installations participating in the EU ETS most likely that is due to the investments in technologies improvements or conversion from energy resources with relatively high GHG emission factor to energy resources with relatively low or "zero" GHG emission factor.

6. The reductions of GHG emissions achieved by the EU ETS participants in Latvia at the end of the first decade of the $21^{\text {st }}$ century on overall are suppressed by the increase of GHG emissions attributed towards economic growth.

\section{ACKNOWLEDGEMENTS}

This paper has been supported by the European Social Fund within the project „Support for Doctoral Studies at University of Latvia".

\section{REFERENCES}

1. Cabinet of Ministers Decree No. 348 "Par emisijas kvotu sadales plānu 2008.-2012.gadam", 01.08.2011. [Accessed 01.03.2012.]. Available: http://www.likumi.lv/doc.php?id=234033

2. Community Transaction Log. Accounts. [Accessed 01.03.2012.] Available: http://ec.europa.eu/environment/ets/account.do? languageCode=en

3. Community Transaction Log. Allocation / Compliance. [Accessed 20.12.2011.]. Available: http://ec.europa.eu/environment/ets/ allocationComplianceMgt.do?languageCode=en
4. Community Transaction Log. Transactions. [Accessed 01.03.2012.]. Available: http://ec.europa.eu/environment/ets/ transaction.do?languageCode $=$ en

5. Crocker T. Structuring of Atmospheric Pollution Control Systems - The Economics of Air Pollution, New York : W.W. Norton \& Co, 1966. pp. 61-86.

6. Dales J.H. Pollution, Property and Prices: an Essay in Policymaking and Economics, Toronto : University of Toronto Press, 1968. pp. 109-111.

7. Directive 2003/87/EC of the European Parliament and of the Council of 13 October 2003 Establishing a Scheme for Greenhouse Gas Emission Allowance Trading Within the Community and Amending Council Directive 96/61/EC, OJ L 275, 25.10.2003 [Consolidated version of Directive with amendments until 23 April 2009]. [Accessed 01.03.2012.]. Available: http://eurlex.europa.eu/LexUriServ/LexUriServ.do?uri $=$ CONSLEG:2003L0087: 20090625:EN:PDF

8. Judgment of the General Court of 22 March 2011 - Republic of Latvia v Commission (Case T-369/07), Official Journal of the European Union, C 139/15, 07.05.2011

9. Latvian Environment, Geology and Meteorology Centre. National GHG emission quota register - Reports on GHG Emissions prepared by EU ETS operators. [Accessed 01.03.2011.]. Available: http://www.meteo.lv/public/SEG_registram.html.

10. Linacre, N., Kossoy, A., Ambrosi, P. State and Trends of the Carbon Market 2011. Washington : World Bank, 2011. p. 78.

11. Lursoft. Companies registered in Latvia. [Accessed 20.12. 2011.]. Available: http://www.lursoft.lv.

12. Montgomery W. D. Markets in Licenses and Efficient Pollution Control Programs. Journal of Economic Theory, Vol. 5, No. 3, 1972. pp. 395-418.

13. Tietenberg T. H. Emissions Trading: An Exercise in Reforming Pollution Policy. Washington DC : Resources for the Future, 1985. $238 \mathrm{p}$.

14. Point Carbon. EUA OTC Assessment. [Accessed 01.03.2012.] Available: http://www.pointcarbon.com/news/marketdata/euets/ forward/eua/.

15. United Nations, Kyoto Protocol to the United Nations Framework Convention on Climate Change, 1998, [Assessed 20.07.2011.]. Available: http://unfccc.int/resource/docs/convkp/kpeng.pdf.

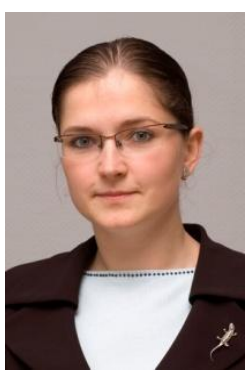

Ilze Prūse has a master's degree in management science, but since 2011 she is a $\mathrm{PhD}$ candidate in economics at the Faculty of Economics of the University of Latvia.

Currently she is the Head of Climate Finance and Technology Division in the Ministry of Environmental Protection and Regional Development of the Republic of Latvia. Her primary responsibilities are the co-ordination of Latvia's participation in the International Emissions Trading as well co-ordination of preparations for EUAs auctioning within the EU ETS.

Her research interest is the EU ETS impact on the sustainable development of Latvia's economy, inter alia assessment of the EU ETS impact on its direct participants and assessment of the EU ETS indirect impact, i.e. its impact on national economy through prices of commodities.

Address: Zeltrītu iela 4-14, Mārupe, Mārupes nov., Latvia, LV-2167

Phone: +371 26370883

E-mail: Ilze.Pruse@yahoo.com 